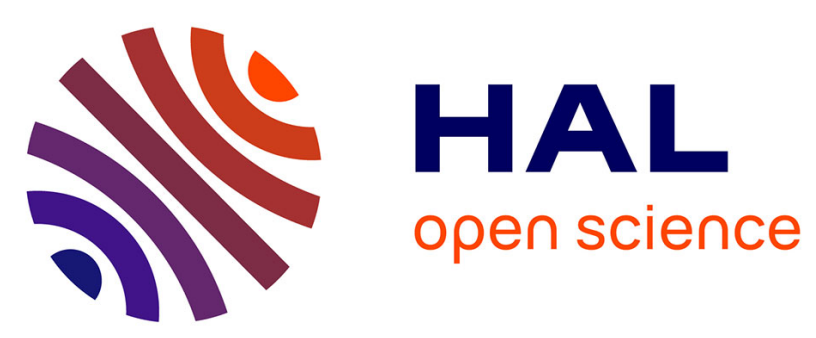

\title{
POPULATION STRUCTURE AND MORPHOMETRICS OF THE EUROPEAN POND TURTLE (Emys orbicularis (LINNAEUS, 1758)) AT LAKE TONGA, ALGERIA
}

Samira Fediras, Rachid Rouag, Nadia Ziane, Anthony Olivier, Arnaud Béchet, Slim Benyacoub

\section{To cite this version:}

Samira Fediras, Rachid Rouag, Nadia Ziane, Anthony Olivier, Arnaud Béchet, et al.. POPULATION STRUCTURE AND MORPHOMETRICS OF THE EUROPEAN POND TURTLE (Emys orbicularis (LINNAEUS, 1758)) AT LAKE TONGA, ALGERIA. Russian Journal of Herpetology, 2017. hal01944353

\section{HAL Id: hal-01944353 \\ https://hal.science/hal-01944353}

Submitted on 4 Dec 2018

HAL is a multi-disciplinary open access archive for the deposit and dissemination of scientific research documents, whether they are published or not. The documents may come from teaching and research institutions in France or abroad, or from public or private research centers.
L'archive ouverte pluridisciplinaire HAL, est destinée au dépôt et à la diffusion de documents scientifiques de niveau recherche, publiés ou non, émanant des établissements d'enseignement et de recherche français ou étrangers, des laboratoires publics ou privés. 


\title{
POPULATION STRUCTURE AND MORPHOMETRICS OF THE EUROPEAN POND TURTLE (Emys orbicularis (LINNAEUS, 1758)) AT LAKE TONGA, ALGERIA
}

\author{
Samira Fediras, ${ }^{1}$ Rachid Rouag, ${ }^{2 *}$ Nadia Ziane, ${ }^{1}$ Anthony \\ Olivier, ${ }^{3}$ Arnaud Béchet, ${ }^{3}$ and Slim Benyacoub ${ }^{1}$
}

\author{
${ }^{1}$ Université Badji Mokhtar. Département de Biologie. BP. 12. El Hadjar. 23000 Annaba, Algeria. \\ ${ }^{2}$ Université Chadli Bendjedid. 36100 El Tarf, Algeria; e-mail: rachid_rouag@yahoo.fr \\ ${ }^{3}$ Institut de recherche de la Tour du Valat, Le Sambuc, 13200 Arles, France. \\ * Corresponding author. \\ How to cite : \\ Fediras S., Rouag R., Ziane N., Olivier A., Béchet A., Benyacoub S. 2017. Population Structure and Morphometrics of the European \\ Pond Turtle (Emys orbicularis (Linnaeus, 1758)) at Lake Tonga, Algeria. Russian Journal of Herpetology 25:88-96.
}

\begin{abstract}
A total of 100 specimens of Emys orbicularis were collected and marked at Lake Tonga (northeastern of Algeria) during 3 consecutive years $(2013,2014,2015)$. Most of the turtles inhabit a canal where they remain throughout the whole activity season (March to October) and where they overwinter as well. Carapace Length (CL) and body weight (BW) were measured for each individual of E. orbicularis. The size of the turtles of our population was more similar to those of northern European populations than to the Mediterranean populations; females were significantly larger than the Spanish and Italian populations. The population size was calculated as 108.50 and the density as 8.63 turtles/ha. From 6.52 to $12.77 \%$ of the population were juveniles. The adult sex ratio was slightly in favor of males (males:females $=$ $1.12, P<0.005)$.
\end{abstract}

\section{INTRODUCTION}

The European Pond Turtle, Emys orbicularis (Linnaeus, 1758) is one of the most widely distributed water turtle species ranging from Northwestern Africa in the west to the former Aral sea in the east, and from the Latvia in the north to the Turkish-Syrian border in the south (Fritz 2001, 2003). Populations of the European pond turtle are considered endangered in several parts of their range (Servan, 1999; Fritz and Andreas, 2000). The populations of the species are threatened by destruction and disappearance of their habitats, pesticide use, habitat loss and alteration, and agriculture (Fritz, 2001, 2003). The population ecology of European populations of E. orbicularis has been studied by many authors during the last two decades (Fritz, 2003). However, very little information is available on Maghreb populations (Fahd et al., 2009; Donaire et al., 2011). Phylogenetic studies have suggested that the eastern Algerian and Tunisian pond turtles represent an undescribed distinct subspecies (Fritz and Havaš, 2007; Stuckas et al., 2014). However, their population structure and morphometrics remains unknown (Fritz, 1993). In this paper, we study the population structure (age structure, population size, density and sex ratio) and morphological parameters (size structure and weight) of an Algerian population of E. orbicularis. The study took place at Lake Tonga, in the National Park of El Kala, Algeria, in a region where E. orbicularis has never been studied before even if it may represent an important geographical refuge for the north-African subspecies of this chelonian. We compare our results to other populations in the Mediterranean and in Europe.

\section{MATERIAL AND METHODS}

Study area. This study was carried out in the National Park of El Kala, in north-eastern Algeria. The study area is a part of the north-eastern Algerian Tell (De Belair, 1990). The climate is Mediterranean (Seltzer, 1946; Toubal, 1986) with moderate rainfall concentrated during winter months. Total annual rainfall was about $630 \mathrm{~mm}$, and the mean monthly rainfall was about $52 \mathrm{~mm}$. The study was carried from March to August in 3 consecutive years $(2013-2015)$ in the "Canal Messida" situated in the north of Lake Tonga $\left(36^{\circ} 53 \ni \mathrm{N}^{\circ} 31^{\prime}\right.$ E). The lake is about 2500 ha with a shallow water body covered by extensive vegetation beds of emergent and floating-leafed plants. It represents one of the most important freshwater areas of northeastern Algeria 


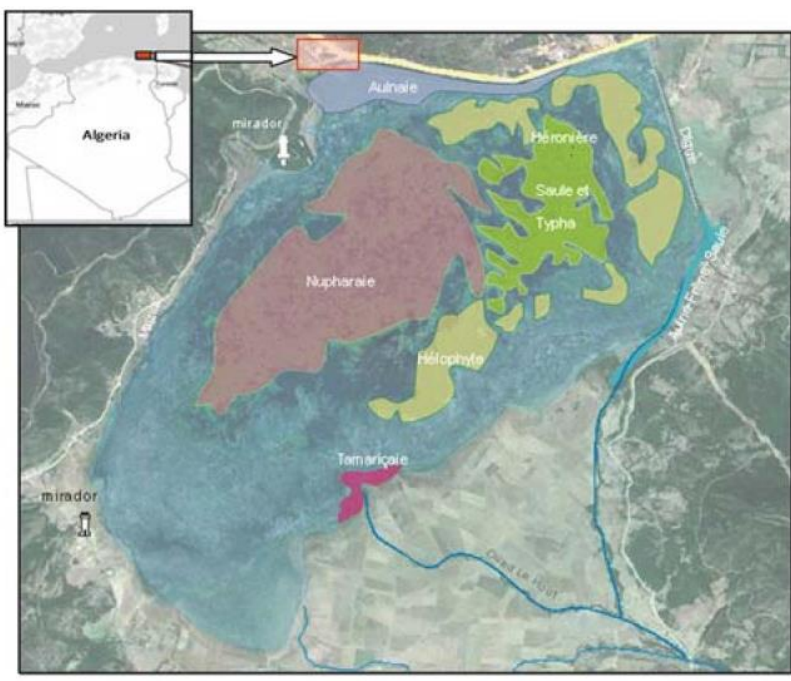

Figure 1 Location of Lac Tonga with major vegetation types and study area.

(Fig. 1). The main plant species are common reed (Phragmites australis Cav.) and lesser reed mace (Typha angustifolia L.) with some admixture of common bulrush (Scirpus lacustris L.), branched burred (Sparganium erectum L.), and yellow iris (Iris pseudoacorus L.). The submerged and surface-floating vegetation of this lake is dominated by white water-lily (Nymphea alba L.), pondweeds (Potamogeton lucens L.), and water-milfoil (Myriophyllum verticillatum L.) (Bakaria et al., 2009). The Mediterranean pond turtle (Mauremys leprosa) is another freshwater turtle which is also present in the study site.

Fieldwork. Only caught by hand method was used in this work because of the lack of traps especially fyke nets, ideal to catch turtles. The turtles were caught in an area of 5 ha of the entire canal. The coastal strip is inspected, and when a turtle is observed in the shallow area, we usually use a net to catch it. Four surveys sessions by one people were carried out. The session consist of the prospection of the canal from 10:00 to 16:00 h. Five in 2013 (from 21 March to 15 August), 6 in 2014 (from 27 March to 18 August), and three in 2015 (from 12 March to 24 August). An interval of at least two week separated the surveys to facilitate the redistribution of the individuals (Gibbons, 1990). From 2013 to 2015, a total of 100 European Pond Turtles were marked by notching its marginal scutes

marked, particularly the ${ }^{+1}$ notching. On every specimen $_{+} 1$ before the release of the

(Cagle, 1939). Measures have been taken when turtles are disinfection of the lime, as well as scutes before and after the caught, seven morphometrical variables were measured (Fig. 3) individual on the site of capture. Carapace length was measured by a digital caliper (precision $\pm 0.1 \mathrm{~mm}$ ) with thesame measurement criteria as in Stubbs and Swingland (1984). Body mass of the turtles was measured using a digital balance (precision $\pm 1 \mathrm{~g}$ ). Sex was determined by secondary sexual characters (e.g., plastral concavity and tail length) (Servan et al., 1989). Turtles of less than $12 \mathrm{~cm}$ were considered too small to be sex reliably and were classified as juveniles.

Statistical analyses. Population size was estimated using capture-mark-recapture procedures. This method consists in the capture of a certain number of individuals within a natural population, their marking and releasing to the capture point, during a "first capture survey." Then, after a period with no surveys, a "second recapture survey" is done. Population size (N) was determined by Lincoln-Petersen-Bailey formula (1951) for small sample sizes ( $m: 920)$ :
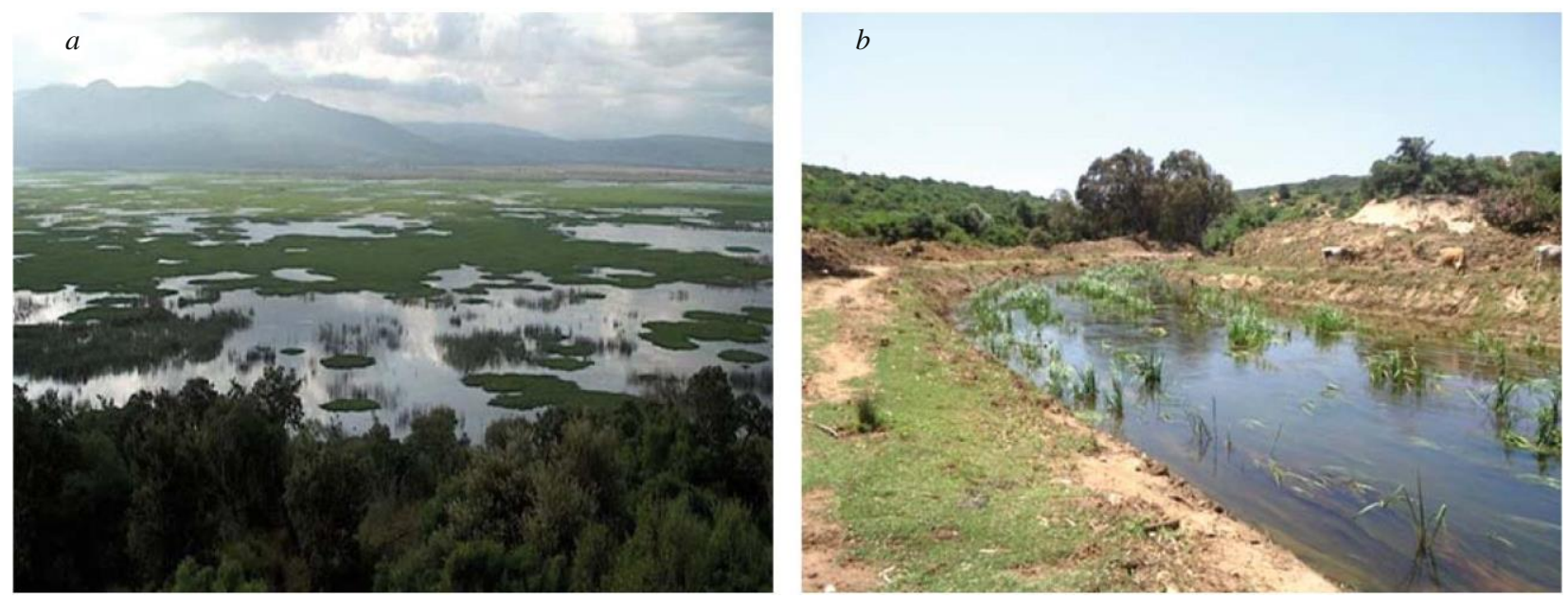

Figure 2 General view of the Tonga Lake; b, view of the Messida canal. Photo by S. Fediras. 


$$
N=M \frac{n+1}{m+1},
$$

where $M$ is the sample of individuals that were captured, marked and measured during the first survey period, $n$ is the number of individuals captured during the second survey period, and $\mathrm{m}$ is the number of individuals, captured during the second survey period, that were already marked.

Population density $(d)$ was estimated as $d=N / a$ with $N$ the mean population size and a the sampled area (5 ha).

Age was estimated by counting the number of growth annuli on the shell (Castanet, 1988; Germano and Bury, 1998).
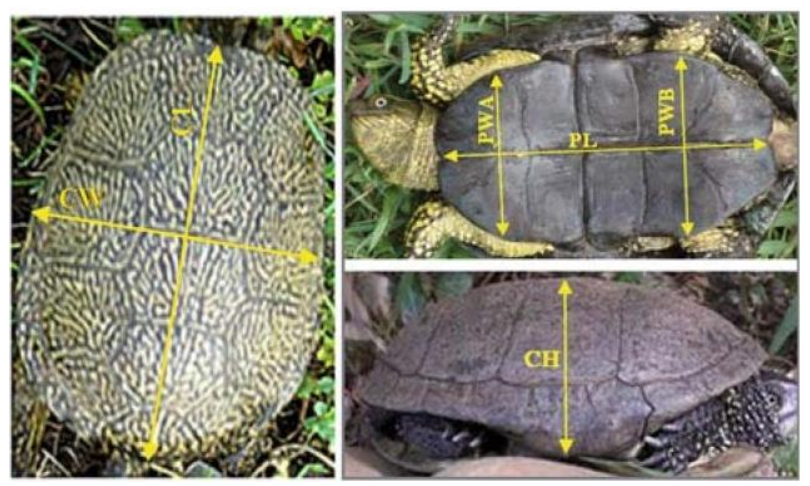

Figure 3 Morphometrical variables of Emys orbicularis (for abbreviations see Table 3). Photo by S. Fediras The exact age was difficult to determine on large old turtles by counting annular rings; therefore those turtles were classified as adults on class age superior to 10 years. We used the carapace length to estimate the growth rates, and placed this measure against the age of the various individuals (Barbault, 1973). The instantaneous growth rate (IGR) was expressed in mm per time unity $(j)$ according to the following formula:

$\mathrm{IGR}=\frac{\mathrm{CL}_{2}-\mathrm{CL}_{1}}{t_{2}-t_{1}}$,

lengths of the animal at the time $t_{2}$ and $t$.

The growth rate estimates were generated from the turtle's

individuals which were first captured in 2013 and then recaptured in 2014 and 2015. We also omitted turtles for which the time between capture and recapture was less than 1 year, in order to ensure that the growth inter-vals cover at least an entire growing season. All statistical analyses were done by the Excel software and Minitab ${ }^{\circledR}$ 15.1.30.0.

Data collected was used for the estimation of statistical description range (average, standard deviation, range), while the univaried statistics ( $t$-test) was used to analyze the differences between genders.

\section{RESULTS}

Population size. During the period of the study from 2013 to 2015, a total of 100 individuals was captured. The number of individuals captured did not differ from one year to another, being 47 turtles in 2013 and 2014; and 46 individuals in 2015 (Table 1). The mean size of the population for the tree years is 46.66 individuals. Adults dominate the population with $87.23 \%$ (2013) to $95.74 \%$ (2014) of individuals caught for $4.26 \%$ (2014) to $12.77 \%$ (2013) of juveniles.

Density. The population density was estimated as 8.63 turtles/ha.

Sex ratio. The sex ratio was in favor of males 1.14:1 in 2014 and in favor of females 0.78:1 and 0.79:1 in 2013 and 2015, respectively. When the whole study period was considered, the sex ratio was found as $1.12: 1\left(\div^{2}=25.06, P<0.0001\right)$ and it was male-biased.

Age structure. Adults dominate the population of E. orbicularis in the study area (89\%) for the three years

Tableau 1 Number of Individuals Captured Each Year and Estimation of Abundance Obtained by Lincoln Inde

\begin{tabular}{|c|c|c|c|c|c|c|}
\hline & \multicolumn{2}{|c|}{$2013(n=47)$} & \multicolumn{2}{|c|}{$2014(n=47)$} & \multicolumn{2}{|c|}{$2015(n=46)$} \\
\hline & Session A & Session B & Session A & Session B & Session A & Session B \\
\hline$M$ & 9 & 14 & 8 & 19 & 6 & 10 \\
\hline$n$ & 8 & 20 & 8 & 12 & 8 & 8 \\
\hline$m$ & 1 & 4 & 4 & 5 & 7 & 1 \\
\hline$N$ & 81 & 58.8 & 18 & 49.4 & 6.75 & 45 \\
\hline Average & \multicolumn{2}{|c|}{69.9} & \multicolumn{2}{|c|}{33.7} & \multicolumn{2}{|c|}{25.88} \\
\hline
\end{tabular}

Note. 2013: Session A, capture March 28 - 31, recapture April 12-15; Session B: capture May 20 - 22, recapture June 26 - 30. 2014 : Session A: capture March 27 - 30, recapture April 18 - 20; Session B: capture June 17 - 23, recapture July 08 - 14. 2015: Session A: capture March 12 - 14, recapture April 20 - 23; Session B: capture May $22-24$, recapture July $08-11$.

while juveniles are represented by a few individuals $(11 \%)$.

Mean age of captured terrapins was $8.32 \pm 2.73$ years $(N=100)$. Ages classes between $5-6$ and $9-10$ years were represented by the same rate $(21.0 \%)$. The individuals with age from 7 to 8 accounted for $27 \%$ of the population. 
Individuals $>10$ years old, represented $23 \%$ of the population. Males are few represented in this age classes $(6 \%)$, most of the individuals being females (17\%). The age classes 1 to 4 (juveniles) accounted for $8 \%$ of the population.

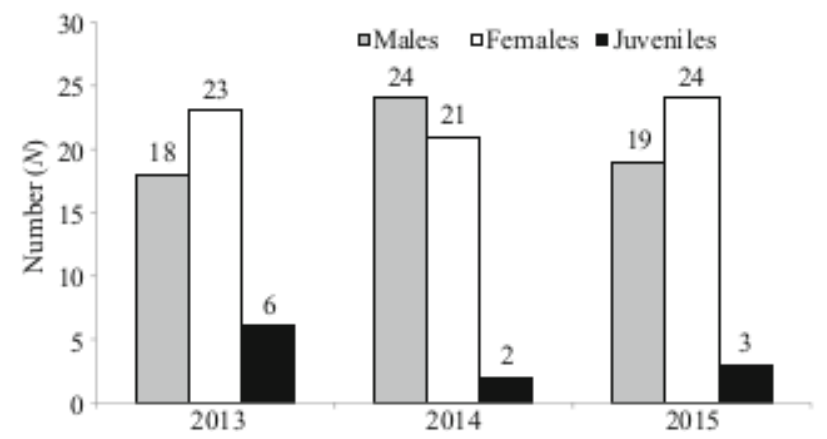

Figure 4 Variation in population catch by sexes and ages for the tree years $(N=140)$.

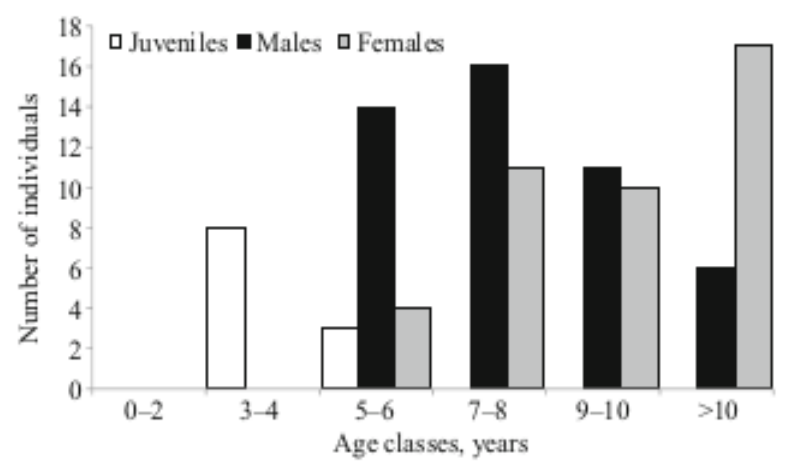

Figure 5 ree years $(\mathrm{N}=100)$. Age structure of the population of Emys orbicularis during th

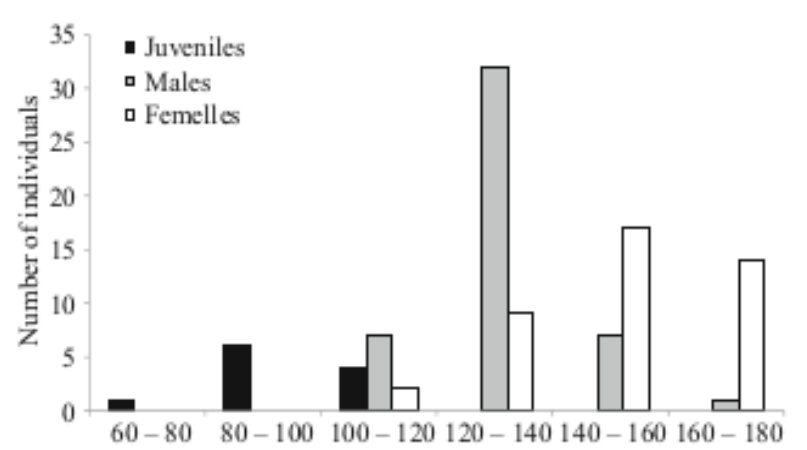

Figure 6 Size structure of the population of Emys orbicularis during three years $(\mathrm{N}=100)$.

\begin{tabular}{lcccc}
\hline & 2013 & 2014 & 2015 & Total \\
\hline The number of males & 18 & 24 & 19 & 47 \\
The number of females & 23 & 21 & 24 & 42 \\
Sex ratio (males:females) & $0.78: 1$ & $1: 1.14$ & $0.79: 1$ & $1.12: 1$ \\
$\chi^{2}$ & 28.95 & 28.65 & 12.36 & 25.06 \\
$P<$ & 0.0001 & 0.0001 & 0.05 & 0.0001 \\
\hline
\end{tabular}

Tableau 2Population Sizes and Sex Ratio of Emys orbicularis on the Study Area
Sexual dimorphism. Males and females differed significantly in terms of both carapace length (males: 130.65 $\pm 10.57 \mathrm{~mm}$, range $110.01-161.20 \mathrm{~mm}$; females: $151.00 \pm$ $18.96 \mathrm{~mm}$, range $110.10-179.67 \mathrm{~mm} ; P<0.0001$ at $t$-test) and weight (males: $326.06 \pm 110.13 \mathrm{~g}$, range: $225-808 \mathrm{~g}$; females: $548.40 \pm 200.28 \mathrm{~g}$, range $225-814 \mathrm{~g} ; P<0.0001$ at $t$-test). For juveniles, the average carapace length and weight were respectively $91.41 \pm 13.45(69.03-110.36) \mathrm{mm}$ and $144.84 \pm 55.80(88-225)$ g. From biometrical parameters, it is clearly seen that for all parameters, the average values were higher in females individuals. The ( $t$-test) shows statistically $(p<0.0001)$ differences between males and females for all variables (Table 3 ).

Size structure. All captured individuals of E. orbicularis were separated in six different size classes based on their carapace length (CL). Turtles were allocated into $20 \mathrm{~mm}$ size classes (length frequency distribution), where the first size class was from $60-80 \mathrm{~mm}$, the second from $80-100 \mathrm{~mm}$ and till the last one, that was from $160-180 \mathrm{~mm}$. First, altogether individuals of $E$. orbicularis were classified according to size. Adult males are better represented with classes of sizes between 120 and $140 \mathrm{~mm}(68.09 \%)$. In adult females, size class between 140 and 160 is represented with $40.48 \%$ of the size frequency. The typical size class for juveniles is $80-100$

$\mathrm{mm}$ with $54.55 \%$ of the size frequency.

Growth. A relative constancy of the size of the individuals based on their weight is observed both in males ( $r$ $=0.91, p<0.0001)$ and in females $(r=0.95, p<<0.0001)$ with a net increase of size and body weight in females (Fig. 7).

The analysis of the growth curve (Fig. 8) for the population revealed that it is more important in females than in males. The growth is quick during the early years and tended to decreases by the $12 \mathrm{t}^{\mathrm{h}}$ year of life. More precisely, the growth of the males tended to slowdown and to eventually stop by age $10-11$ years old. For female, the growth continues beyond 12 year-old. 


\begin{tabular}{|c|c|c|c|c|}
\hline Parameter & Males $(N=47)$ & Females $(N=42)$ & $t$ & $p$ \\
\hline Carapace length CL, mm & $130.65 \pm 10.57(110.01-161.20)$ & $151.00 \pm 18.96(110.10-179.67)$ & 1.988 & $<0.0001$ \\
\hline Carapace height $\mathrm{CH}, \mathrm{mm}$ & $49.07 \pm 5.54(41.02-65.14)$ & $63.33 \pm 9.06(41.23-80.37)$ & -9.058 & $<0.0001$ \\
\hline Carapace width $\mathrm{CW}, \mathrm{mm}$ & $103.27 \pm 7.48(90.12-125.75)$ & $118.02 \pm 15.31(90.31-142.31)$ & 3.591 & $<0.0001$ \\
\hline Plastron length PL, mm & $114.24 \pm 10.43(99.03-150.40)$ & $140.60 \pm 19.37(98.10-168.91)$ & -8.393 & $<0.0001$ \\
\hline Plastron PWA, mm & $68.56 \pm 6.63(59.01-92.30)$ & $86.44 \pm 13.81(59.05-108.88)$ & -17.876 & $<0.0001$ \\
\hline Plastron PWB, mm & $59.43 \pm 5.58(49.17-76.50)$ & $73.60 \pm 9.96(51.14-89.45)$ & -14.171 & $<0.0001$ \\
\hline Body weight BW, g & $326.06 \pm 110.13(225-808)$ & $548.40 \pm 200.28(225-814)$ & 1.988 & $<0.0001$ \\
\hline
\end{tabular}

Tableau 3 Biometrical Data (Mean t SD, range); t-Test (t) and Level of Significance (p) Between Males and Females (á = 0.05)

The instantaneous growth rate of five turtles ( 2 males, 2 females, and 1 juvenile) that were recaptured in multiple years during the study period (Table 4) indicated that the mean IGR for the males $\left(24.392 \times \times 10^{-3} \mathrm{~mm} /\right.$ day $)$ corresponded to an average growth rate of $8.90 \mathrm{~mm} /$ year. For females, the mean IGR was $26.218 \times 10^{-3} \mathrm{~mm} /$ day, i.e., a growth rate of $9.57 \mathrm{~mm} /$ year. For the juvenile, the IGR is $\left(49.632 \times \times 10^{-3} \mathrm{~mm} /\right.$ day $)$ corresponded to a growth rate of 18.12 $\mathrm{mm} /$ year. As expected, the growth of juveniles is two times faster than that of males and females. These values

\begin{tabular}{|c|c|c|c|c|}
\hline \multirow{2}{*}{ Sex } & \multirow{2}{*}{$\begin{array}{c}\text { Time intervals } \\
\text { between two recap- } \\
\text { tures (No. of days) }\end{array}$} & \multicolumn{2}{|c|}{$\mathrm{CL}, \mathrm{mm}$} & \multirow{2}{*}{$\begin{array}{c}\text { IGR, } \\
\text { mm/day }\end{array}$} \\
\hline & & at $t_{1}$ & at $t_{2}$ & \\
\hline Juvenile & 1088 & 69 & 123 & 0.0496 \\
\hline Female & 788 & 151 & 168 & 0.0216 \\
\hline Female & 348 & 158.26 & 169 & 0.0309 \\
\hline Male & 1086 & 106 & 137 & 0.0285 \\
\hline Male & 1087 & 120 & 142 & 0.0202 \\
\hline
\end{tabular}
confirm the growth curve that is quick in early years. These values also indicate that the growth of females is greater than that of males.

Notes. CL, carapace length; IGR, instantaneous growth rate.

Tableau 4 Individual Growth of Five Recaptured Individuals of Emys orbicularis at the Study Area

\section{DISCUSSION}

Density. the density of our population (8.63 turtles/ha) is close to the one found in the Po Delta Region (northern Italy) with 6.13 individuals/ha Mazzotti (1995). Important densities were reported for Turkey where 81 turtles/ha were found at Lake Yayla (Ayaz et al., 2007) and up to 225 turtles/ha at Cukurkoy (Western Anatolian) (Auer and Taskavak, 2004). In

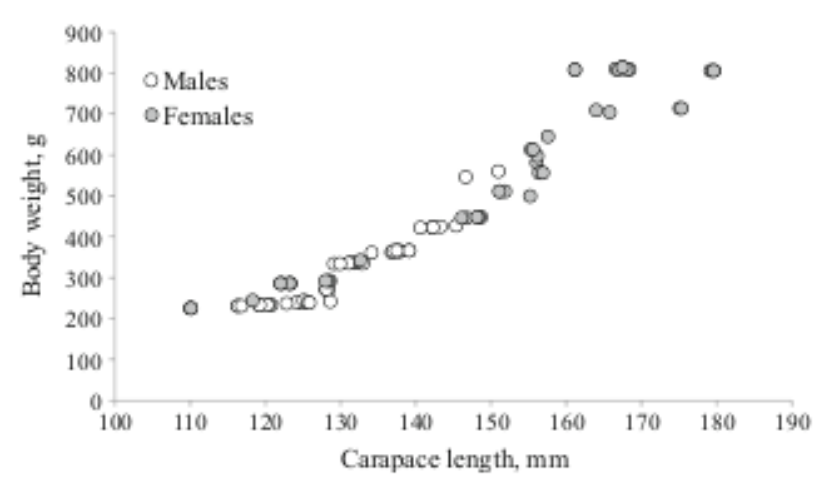

Figure 7Linear regression of body weight (BW) on carapace length (CL) for Emys orbicularis captured during 3 years $(\mathrm{N}=$ 100). other regions, there were much higher densities, such as in La Selva County (north-eastern Spain) where estimated density is 1030.60 individuals/ha (Ramos et al., 2009). It should be noted that the lack of traps especially fyke nets, ideal for catching turtles is the main cause of the low number turtles captured. Fyke nets are adapted to a site with deep water, more efficient in terms of catch because of larger. The catch by hand is very difficult and time-consuming (Woodbury, 1956). We estimate that only $10 \%$ of the observed turtles were caught during the capture-recapture sessions. However, it is necessary to combine these two methods (hand caught and trapping), since none, used alone, gives a complete description of the structure of the population (Servan, 1986; Ream and Ream, 1966). They are biased by the behavior of different age groups (Ream and Ream, 1966). 
Body size. Sexual dimorphism is related to differences in history strategies of both sexes (Olivier, 2002). When smaller males could be advantaged in their mobility and/or search for sexual partners; females tend to a larger size which can be correlated with the clutch size (Olivier, 2002). We found that females were larger than males in size as in most Emys orbicularis subspecies (Zuffi et al., 1999; Fritz, 2001, 2003; Ayres and Cordero, 2001). Also in Algerian, pond turtle population, females (151.00 mm of length and $548.40 \mathrm{~g}$ of weight) are larger than males (129.43 mm of length and $321.21 \mathrm{~g}$ of weight). The plastron width is significantly higher in females than in males, and especially the posterior part of the plastron $(p<0.0001, t$-test). Considering that there is a positive correlation between the numbers of laid eggs and female size (Mitrus and Zemanek, 1998; Zuffi et al., 1999), as in most Emys orbicularis subspecies (Zuffi

et al., 1999; Fritz, 2001, 2003). The body sizes vary depending on latitude and environmental factors (Fritz, 2001, 2003) with the populations in the southern area tending to be smaller (Fritz 1998; Keller et al., 1998). Similar observations with respect to latitude were made also in Chrysemys picta (Moll, 1973; Iverson and Smith, 1993).

Quite surprisingly, the size of the individuals of our population was more similar to the size of northern European populations than to the size of the Mediterranean turtles. Females were significantly larger than the Spanish and Italian populations and smaller than the French, German and Polish populations (Table 5). A possible explanation come from Phylogenetic studies which suggested that the eastern Algerian pond turtles represent an undescribed distinct subspecies (Fritz and Havaš, 2007; Stuckas et al., 2014). The environmental effect (phenotypic) also seems to play, but within the limits imposed by the genotypic effect (phylogenetic constraints) (Lombardini and Cheylan, 2004).

Sex ratio. In an animal species, the sex ratio is a very important ecological factor, which influences the dynamics ofpopulations (Girondot and Pieau, 1993). According to Fisher (1929), the optimum primary sex ratio should be 1:1, but several studies have shown the existence of unbalanced sex ratios (Gibbons, 1990). In the Emydidae family, this ratio varies. Such variations are due to sampling errors (Bury, 1979), mortality rate (Girondot and Pieau, 1993), or different behavior between sexes (Kofron and Schreiber, 1987; Dodd, 1989) influencing capture. Valdeôn (2006) in Navarra obtained preliminary data with a sex ratio 1:1. Ayllon et al. (2010) in Cuenca (Spain), find a sex ratio biased towards males (3.6:1) and it is the case for other Iberian populations (Keller, 1997; Cordero-Rivera and Ayres-Fernandez, 2004; Segurado et al., 2005; Ayres and Cordero, 2001). This is the case of our population during 3 years, when the total number of males was higher than females and the sex ratio was biased for males (1.12:1). Inversely, very variable sex ratio values have been measured in Italian samples of Emys orbicularis, between 1:1 and 1:2.4 (Mazzotti, 1995; Zuffi and Gariboldi, 1995; Mazzotti et al., 2007).

Age structure. The maximum age was 16 years for a male caught in 2014 and 14 years in two females caught in 2015. Auer and Taskavak (2004) reported maximum age almost identical to the one found in our study (i.e., 16 years). In Doñana, data estimated at 28 to 29 the maximum age for males and females respectively (Keller et al., 1998). The age structure of the

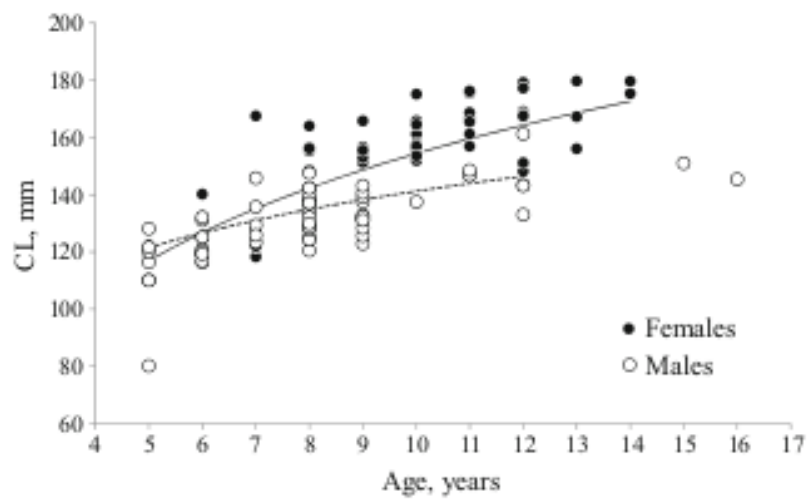

Figure 8 Growth of carapace length of Emys orbicularis. population is quite common in chelonians, with a majority of adults and a small percentage of juveniles. However, we did not capture hatchlings in the site. This may be explained by the threatened factor, where juveniles stay more hidden in the vegetation and do not show up very often. This is the case for the population of Camargue Gardoise (Lyet and Cheylan, 2002) and the Ebro Delta in Spain (Bertolero, 2000). This mainly reflects different behavior between adults and juveniles (Ayres and Cordero, 2007). It is possible that the aquatic habitats where used differently by adults and juveniles (Olivier, 2002). Finally, it is possible that bias is due to the capture method since hatchlings are smaller and therefore difficult to detect and our sampling was carried by hand. Predation pressure can also be a cause of low numbers of hatchlings, extremely vulnerable because of their soft shells. 


\begin{tabular}{|c|c|c|c|c|c|}
\hline Area & Sex & $N$ & $\mathrm{CL}, \mathrm{mm}$ & $\mathrm{BW}, \mathrm{g}$ & References \\
\hline \multirow{2}{*}{$\begin{array}{l}\text { Germany } \\
\text { (north eastern) }\end{array}$} & Females & \multirow{2}{*}{31} & 182.8 & & \multirow[t]{2}{*}{ Schneeweis, 1998} \\
\hline & Males & & 160.3 & & \\
\hline \multirow[t]{2}{*}{ Poland (central) } & Females & \multirow{2}{*}{38} & 182.7 & & \multirow[t]{2}{*}{ Mitrus and Zemaneck, 2000} \\
\hline & Males & & 171.8 & & \\
\hline \multirow{2}{*}{$\begin{array}{l}\text { Germany } \\
\text { (north eastern) }\end{array}$} & Females & 22 & $173(143-197)$ & \multirow{2}{*}{-} & \multirow[t]{2}{*}{ Farkas et al., 1998} \\
\hline & Males & 21 & $159(131-178)$ & & \\
\hline \multirow[t]{2}{*}{ West Poland } & Females & 33 & $171(137.90-198.50)$ & $790.66(438-1380)$ & \multirow[t]{2}{*}{ Najbar et al., 2006} \\
\hline & Males & 28 & $154.40(133.30-185.50)$ & $554.2(345-815)$ & \\
\hline \multirow{2}{*}{$\begin{array}{l}\text { Southem France } \\
\text { (Camargue) }\end{array}$} & Females & 183 & 163.3 & $744.6(670-1092)$ & \multirow[t]{2}{*}{ Olivier, 2002} \\
\hline & Males & 130 & 145.4 & $436.7(286-670)$ & \\
\hline \multirow[t]{2}{*}{ Westem France } & Females & \multirow{2}{*}{50} & 159.7 & & \multirow[t]{2}{*}{ Duguy and Baron, 1998} \\
\hline & Males & & 149.5 & & \\
\hline \multirow[t]{2}{*}{ France (Brenne) } & Females & \multirow{2}{*}{210} & 154 & & \multirow[t]{2}{*}{ Servan, 1988} \\
\hline & Males & & 142 & & \\
\hline \multirow[t]{2}{*}{ Hungary } & Females & & 155 & & Balazs and Gyorffy, 2006 \\
\hline & Males & 978 & 130 & & \\
\hline Hungary & Females & & 152 & & Farkas et al., 1998 \\
\hline & Males & 97 & 135 & & \\
\hline Algeria (EI kala) & Females & 68 & $151.00(110.10-179.67)$ & $548.40(225-814)$ & Current study \\
\hline & Males & 61 & $130.65(110.01-161.20)$ & $326.06(225-808)$ & \\
\hline$\overline{\text { Corsica }}$ & Females & & 147.5 & & Lombardini and Cheylan, 2004 \\
\hline & Males & 151 & 134.3 & & \\
\hline France (Aquitaine) & Females & & 144 & & Priol, 2009 \\
\hline & Males & 1471 & 131 & & \\
\hline Donana & Females & & 142.6 & & Keller et al., 1998 \\
\hline (southem Spain) & Males & 778 & 138.9 & & \\
\hline Italy & Females & & 137.6 & & Zuffi and Gariboldi, 1995 \\
\hline (Emilia-Romagna) & Males & 126 & 112.5 & & \\
\hline Ebre delta (Spain) & Females & & 137.4 & & Bertolero, 2001 \\
\hline & Males & 24 & 119.6 & & \\
\hline Southem France & Females & 60 & 137 & & Parde et al., 2000 \\
\hline (Gers) & Males & 63 & 130 & & \\
\hline Turkey & Females & & 135.4 & & Ayaz et al. 2008 \\
\hline & Males & 1216 & 128.5 & & \\
\hline Central Italy & Females & 25 & 131.7 & 483.4 & Zuffi et al., 1999 \\
\hline & Males & 45 & 125.9 & 233 & \\
\hline Sardinia (Italy) & Females & & 125.2 & & Schulze and Fritz, 2003 \\
\hline & Males & 24 & 117.9 & & \\
\hline East Spain (Valencia) & Females & 161 & $124.39(80.7-156)$ & $338(84-631)$ & Bataller et al., 2008 \\
\hline & Males & 113 & $119.15(89.9-158.4)$ & $279(114-428)$ & \\
\hline Northwestern Spain & Females & 115 & 122.6 & 352.6 & Ayres and Cordero, 2001 \\
\hline & Males & 66 & 136.4 & 408 & \\
\hline Italy (Calabria) & Females & & 121.4 & & Tripepi and Zuffi, 2002 \\
\hline & Males & 84 & 108.2 & & \\
\hline Italy (Lat ium) & Females & & 121.2 & & Rovero et al., 1999 \\
\hline & Males & 33 & 112.8 & & \\
\hline Pô delta (Italy) & Females & & 119.5 & & Mazzotti, 1995 \\
\hline & Males & 127 & 111.2 & & \\
\hline Southem Italy & Females & 43 & $119.9(97-152)$ & $297.6(142-600)$ & Fattizzo, 2008 \\
\hline & Males & 26 & $109.2(90-128)$ & $199.6(120-300)$ & \\
\hline Turkey & Females & & 119.1 & & Taskavak and Reimann, 1998 \\
\hline (Central Anatoly) & Males & 94 & 105.4 & & \\
\hline
\end{tabular}

Tableau 5Average Carapace Lengths (CL) and Average Body Weights (BW) of the Algerian Population Compared with Various European Populations (in decreasing order of carapace length of females

Size structure. In our population juveniles are few the three years, especially with the class size between $60-120 \mathrm{~mm}$. This rate is higher in other populations such as Doñana, Spain (20\%) (Keller, 1997) and Brenne, France (30\%) (Servan, 1989). Braitmayer et al. (1998) found $12 \%$ juveniles in Menorca. This percent can be very low in some population as in 
Çukurköy (western Turkey) where the rate is only $1.9 \%$. The major difference between males and females is the size over $160 \mathrm{~mm}$ which is more represented in females with an average percent of $38 \%$ and with only $5.56 \%$ in males.

Growth rates. The only juvenile recaptured has a much higher growth than adults with $19.8 \%$ of growth rate. The growth trajectories are characterized by a faster growing period at the youth age and a slow growth trajectory probably after reaching the sexual maturity. The growth is much pronounced in female than male, which can explain the difference in body size between the two sexes.

The first results obtained from this work will constitute a basis for more studies on the reproduction strategy, the behavior and the use of the space in order to obtain details of the movements and to verify the zones actually used by the individuals and to highlight the corridors used. This species is not yet protected in Algeria despite

its presence in a National Park and on a site Ramasar, it is often a victim of the operations of clearing the channel which can put the population at risk. Laying sites are also frequently devastated by clearing operations at the lake dykes. The disturbance is also a threat since the site is a touristic area and very frequented especially during the summer. It is, therefore, essential to involve the public, in particular, the users of the wetland (fishermen, farmers, etc.) and tourists in a process of preserving a species that is still vulnerable by the fragility of these habitats. It seems necessary that the various actors involved in wetland conservation, including Chadli Bendjedid University, the management of El Kala National Park, the services of Forests, Hydraulic Services and the services of Agriculture Collaborate to establish long-term conservation strategies for this species.

Acknowledgments. We thank Ayres C.for his valuable corrections and suggestions and anonymous reviewer for helpful comments. We are grateful to Dr. P. Grillas, Program Director in the research center for the conservation of Mediterranean wetlands (Tour du Valat) for receiving us in the research station and for the use of their facilities during our stay. Permits to capture and analyze the turtles used in this study were released by the Director of the National Park of El Kala.

\section{REFERENCES}

Auer M. and Taskavak E. (2004), "Population structure of syntopic Emys orbicularis and Mauremys rivulata in western Turkey," Biologia, 59, $81-84$.

Ayllôn E., Hernândez-Sastre P.-L., Franch, M., Ayres, C., and Álvarez A. (2010), "Datos preliminares sobre la poblaciôn de Emys orbicularis en las lagunas de Cañada de Hoyo (Cuenca)," Bol. Asoc. Herpetol. Esp., 21, 71 - 75.

Ayres C. and Cordero A. (2001), "Sexual dimorphism and morphological differentiation in European pond turtle (Emys orbicularis) populations from northwestern Spain," Chelonian Conserv. Biol., 4, $100-106$.

Bakaria F., Benyacoub S., Gauthier-Clerc M., and Bafibura J. (2009), "Long-term changes in the size, structure and location of whiskered tern Chlidonias hybrida (P.) nests in deteriorating environmental conditions of a north African lake," Polish J. Ecol., 57(4), $749-749$.

Bataller J.-V., Sancho V., Gil J.-M., and Lacomba I. (2008), "La Comunidad Valenciana lucha contra el galápago de Florida," Quercus, 274, $28-34$.

Barbault R. (1973), Structure et dynamique d'un peuplement de lézards: Les Scincidés de la savane de Lamto. Thèse de Doctorat èsSciences, Paris VI. Univ..

Bertolero A. (2000), "Suivi de la population de cistude Emys orbicularis dans le delta de l'Ebre (NE Espagne)," Chelonii, 2, 63 - 66.

Braitmayer N., Fritz U., Mayol J., and Pieh A. (1998), "Die Europaische Sumpfschildkrote (Emys orbicularis) Menorcas," Elaphe, 4, $57-60$.

Bury R.-B. (1979), “Population ecology of freshwater turtles,” in: M. Harless and H. Morlock (eds.), Turtles: Perspective and Research, John Wiley \& Sons, New York, pp. 571602.

Cagle F. R. (1939), "A system for marking turtles for future identification,” Copeia,1939, 170 - 173.

Castanet J. (1988), "Les méthodes d'estimation de l'âge chez les chéloniens," Mésogée, 48, 21 - 28.

Cordero-Rivera A. and Ayres-Fernândez C. (2004), "A management plan for the European pond turtle (Emys orbicularis) populations of the Louro river basin (Northwest Spain)," Biologia. Bratislava, 59(Suppl. 14), 161171.

De Belair G. (1990), Structure, fonctionnement et perspectives de gestion de quatre complexes lacustres et marécageux (Est algérien). Thèse de Doctorat, Université du Languedoc.

Dodd C. K. (1989), "Population structure and biomass of Sternotherus odoratus (Testudines: Kinosternidae) in a northern Alabama lake," Brimleyana, 15, $47-56$.

Donaire D., del Canto-Gonzâlez R., Bogaerts S., Pasmans F., and El Mouden H. (2011), "Nuevas localidades para Emys orbicularis occidentalis Fritz, 1993 (Testudines: Emydidae) en El Rif (Noroeste de Marruecos)," Bull. Soc. Catal. d'Herpetol., 19, 125 - 129.

Fahd S., El Marnisi B., Mediani M., and Fritz U. (2009), "Zur Verbreitung und zum Bedrohungsstatus der Europäischen Sumpfschildkröte (Emys orbicularis) in Marokko," Elaphe, 17, 30 - 33.

Farkas B., Fritz U. Jendretzke N., and Schneeweiss N. (1998), "Morphological differences between pond turtles (Emys orbicularis) from the Hungarian lowlands, eastern Poland, and northeastern Germany," in: U. Fritz, U. Joger, R. Podloucky, and J. Servan (eds.), Proc. of the Emys Symp. Dresden 96, Mertensiella, 10, 89 - 94. 
Fattizzo T. (2008), "Morphological data and notes on natural history of pond turtles Emys orbicularis (Linnaeus, 1758) of southern Apulia (Italy)," Rev. Esp. Herpetol., 22, 2332.

Fisher R. A. (1929), The genetical theory of natural selection, Oxford Univ. Press, Oxford, UK.

Fritz U. (1993), "Zur innerartlichen VariabilitaÈt von Emys orbicularis (Linnaeus, 1758). Zwei neue Unterarten von der Iberischen Halbinsel und aus Nordafrika, Emys orbicularis fritzjuergebnosti subsp. nov. und E. o. occidentalis subsp. nov. (Reptilia, Testudines: Emydidae)," Zool. Abh., 47, $131-155$.

Fritz U. (1998), "Introduction to zoogeography and subspecific differentiation in Emys orbicularis (Linnaeus, 1758)," Mertensiella, 10, $1-27$.

Fritz U. (2001), “Emys orbicularis (Linnaeus, 1758) — Europäische Sumpfschildkrote,” in: U. Fritz (ed.), Handbuch der Reptilien und Amphibien Europas. Band 31IIIA. Schildkroten I, Aula, Wiebelsheim, pp. 343 - 515.

Fritz U. (2003), Die Europaische Sumpfschildkrote, Laurenti, Bielefeld.

Fritz U. and Andreas B. (2000), "Distribution, variety of forms and conservation of the European Pond Turtle," Chelonii, 2,23 - 27.

Fritz U. and Havaš P. (2007), "Checklist of chelonians of the world," Vertebr. Zool., 57, 49 - 368.

Germano D. J. and Bury R. B. (1998), "Age determination in turtles: evidence of annual deposition of scute rings," Chelonian Conserv. Biol., 3, $123-132$.

Gibbons J. W. (1990), "Sex ratios and their significance among turtle populations," in: J. W. Gibbons (ed.), Life History and Ecology of the Slider Turtle, Smithsonian Inst. Press, Washington, pp. $171-182$.

Girondot M. and Pieau C. (1993), "Effects of sexual differences of age at maturity and survival on population sex ratio," Evol. Ecol., 7, $645-650$.

Iverson J. B. and Smith G. R. (1993), "Reproductive ecology of the Painted Turtle (Chrysemys picta) in the Nebraska Sandhills and across its range," Copeia,1993, $1-21$.

Keller C. (1997), Ecología de poblaciones de Mauremys lep-rosa y Emys orbicularis en El Parque Nacional de Doñana. Ph.D. Thesis, Universidad de Sevilla, Spain.

Keller C., Andreu A. C., and Ramo C. (1998), "Aspects of the population structure of Emys orbicularis hispanica from southwestern Spain," Mertensiella, 10, $147-158$.

Kofron C. P. and Schreiber A. A. (1987), "Observations on Aquatic Turtles in a Northeastern Missouri Marsh," The Southwestern Naturalist, 32, $517-521$.

Lyet A. and Cheylan M. (2002), La Cistude d'Europe (Emys orbicularis) en Camargue gardoise - Statut des populations et propositions de mesures de protection, Ecole Pratique des Hautes Etudes de Montpellier.

Mazzotti S. (1995), "Population structure of Emys orbicularis in the Bardello (Po Delta, Northern Italy)," Amphibia- Reptilia, 16, 77 85.

Mazzotti S., Montanari F., Greggio N., and Barocci M. (2007), "La popolazione della testuggine palustre (Emys orbicularis) del Bosco della Mesola," Quad. Staz. Ecol. civ. Mus. St. nat. Ferrara, 17, $117-123$.

Mitrus S. and Zemanek M. (1998), "Reproduction of Emys orbicularis (L.) in Central Poland,” Mertensiella, 10, 187192.

Moll E. (1973), "Latitudinal and intersubspecific variation in reproduction of the Painted Turtle Chrysemys picta," Herpetologica, 29, $307-318$.

Najbar B. and Szuszkiewicz E. (2006), "The morphometrics and coloration of the European pond turtle Emys orbicularis in Lubuskie province (West Poland)," Biologia. Bratislava, 61(5), 585 - 592.

Lombardini K. and Cheylan M. (2004), La cistude dans la réserve de l'étang de Biguglia bilan des recherches 2001 - 2003, Rapport La Réserve Naturelle de Biguglia.

Olivier A. (2002), Ecologie, traits d'histoire de vie et conservation d'une population de Cistude d'Europe Emys orbicularis en Camargue, Laboratoire de Biogéographie et Ecologie des Vertébrés, Ecole Pratique des Hautes Etudes.

Ramos S., Franch M., Llorente G. A., and Montori A. (2009), "Morphometry and biological cycle of a European pond turtle (Emys orbicularis) population from north-eastern Spain,” Rev. Esp. Herpetol., 23, 13 - 24.

Ream C. and Ream R. (1966). "The influence of sampling methods on the estimation of the population structure in Painted turtles," The Am. Midland Naturalist, 75(2), 325 - 338.

Segurado P., Ayres Fernández C., and Cordero Rivera A. (2005), “La cistude d’Europe dans la Péninsule ibérique,” Manouria, 8, 19 -20 .

Seltzer P. (1946), Le climat de l'Algérie. Trav. bits Météo. Et Phys. Du globe, La Typo-Litho, Alger.

Servan J. (1986). "Utilisation d'un nouveau piège pour l'étude des populations de cistudes d'Europe Emys orbicularis (Reptilia, Testudines)," Rev. Ecol. (Terre Vie), 41, $111-117$.

Servan J., Zaborski P., Dorizzi M., and Pieau C. (1989), "Détermination du sexe ratio adulte de la tortue E. orbicularis dans des populations provenant de 7 étangs de Brenne (Indre, France)," Can. J. Zool., 67, 1279 - 1284.

Servan J. (1999), "Réflexions sur la gestion des reptiles et des tortues en particulier en France: 1-La protection des espèces," Bull. Soc. Herpetol. Fr., 90, 5 - 21.

Stubbs D. and Swingland I. R. (1984), "The ecology of the Mediterranean tortoise (Testudo hermanni ): a declining population," Can. J. Zool., 63, 169 - 180. 
Stuckas H., Velo-Antôn G., Fahd S., Kalboussi M., Rouag R., Arculeo M., Marrone F., Sacco F., Vamberger M., and Fritz U. (2014), "Where are you from stranger? The enigmatic biogeography of North African pond turtles (Emys orbicularis)," Organisms Divers. Evol., 14, 295306.

Toubal B. O. (1986), Phytoécologie, biogéographie et dynamique des principaux groupements végétaux du massif de l'Edough (Algérie Nord orientale). Cartographie au 1/25000 USTM. Thèse. Doct. cycle, Univ. Grenoble.

Valdeôn A. (2006), "Datos preliminares de dos poblaciones de galâpago europeo (Emys orbicularis) en el sur de Navarra," in: Libro de resûmenes del IX Congreso Luso-Español de Herpetología, Donosti, pp. 236 - 237.

Woodbury A. M. (1956), "Uses of marking animals in ecology studies: marking amphibians and reptiles," Ecology, 37(4), 670 - 674.

Zuffi M. A. L. and Gariboldi A. (1995), "Sexual dimorphism in Italian populations of the European pond terrapin, Emys orbicularis," in: Lorente G. A., A. Montori, X. Santos, and M. A. Carretero (eds.), Scientia Herpetologica. Proc. 7th Ord. Meet. Soc. Herpetol. Eur. SEH/AHE, Barcelona, pp. $124-124$.

Zuffi M. A. L., Odetti F., and Meozzi P. (1999), "Body size and clutch size in the European Pond Turtle (Emys orbicularis) from central Italy," J. Zool., 247, $139-143$.

Zuffi M. A. L., Celani A., Foschi E., and Tripepi S. (2007), "Reproductive strategies and body shape in the European Pond Turtle (Emys orbicularis) from contrasting habitats in Italy,” J. Zool., 271, $218-224$. 